【カテゴリーIII】

\title{
静穏室内における個別污染源の人体呼吸空気污染への寄与に関する CFD 解析 \\ CFD ANALYSIS ON CONTRIBUTION RATIO OF POLLUTION SOURCE TO BREATHING AIR QUALITY IN A STAGNANT ROOM
}

\author{
林 立也*, 加藤信介**, 村上周三***, 朱 戟 偉****, 梁 禎 訓***** \\ Tatsuya HAYASHI, Shinsuke KATO, Shuzo MURAKAMI, \\ Shengwei $Z H U$ and Jeong-Hoon YANG
}

\begin{abstract}
In this paper, two new indices, CRP1 and CRP2 (Contribution Ratio of Pollution Source 1 and 2), are proposed for evaluating the contribution of an indoor pollution source to human's breathing air quality. CRP1 refers to a ratio indicating how much of the contamination from a pollution source will be inhaled, and CRP2 refers to a ratio indicating how much of the total inhaled contaminant will be from a pollution source. Moreover, CFD methods for the two indices are developed to investigate the breathing air quality of a standing occupant or a lying occupant located in a stagnant room, which is assumed to be air-conditioned by means of displacement ventilation. The results indicate that in such a room, less of the contaminant from the above space will be inhaled by either standing or lying occupant, and it is important to make the floor clean for preventing breathing air from being polluted as expected.
\end{abstract}

Keywords: Contribution Ratio of Pollution Source, Breathing Air Quality, Computational Fluid Dynamics (CFD), Displacement Ventilation 污染寄与率、呼吸空気質、数值流体力学、置換換気冷房方式

1. 序

近年、省エネルギー性、温熱快適性の観点から、建築物の高気密・ 高断熱化が促進され、あらゆる用途の建築物で高気密化が実現され ている。一方で、居室環境ではシックビル症候群などの室内空気污 染問題が顕在化文 12) し、健康・安全な空気環境を確保すべく、住宅 に 24 時間換気が義務付けられるなど法整備も進みつつある。しかし、 従来からの換気設計は完全混合の理論を前提とした換気量（換気回 数）による仕様規定で行われている。実際の室内空気質環境は、污 染源位置の偏在や空調方式、発熱体位置及び換気方式など、多くの 要因に左右され、通常は室内で大きな分布を有している。これに対 し、M. Sandberg 文)らをはじめとして IAQ（Indoor Air Quality）に関

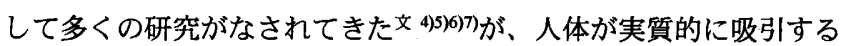
空気を視点とした解析は行われていない。人体が在室する場合、人 体は代謝活動により自らの周辺に微気象（熱上昇流）を形成してお り、この微気象は静稳な室内環境において顕著な空気流動の駆動力 となり、自らが吸引する空気質環境に大きな影響を及ぼしている文8)。 すなわち、ある場所の人体が吸引している空気質環境を厳密に評価 するためには、その場所に実際に存在する人体の呼吸空気を対象と しなければならない。

本研究では人体の呼吸空気の清浄化を目的として、人体に吸引さ れる污染質の起源を評価する指標を新たに定義し、対応する CFD 解
析手法を提案する。CFD 解析においては、実際の人体形状や熱発生 を簡易に再現する人体モデルを取り込み、室内の污染質濃度分布の 検討と合わせて、人体周辺の上昇気流の影響も評価する。なお、本 論文では、提案する指標の解析事例として、置換換気方式により冷 房される室内において、污染発生源位置と人体呼吸空気污染の相関 が人体の姿勢によりどの様に変化するかを検討する。

\section{2. 污染寄与率呼吸}

室内污染源対策を計画する場合、室内のある場所から発生する污 染質が人体にどの程度吸込まれるかは污染源位置と室内の流れ場に 依存する。そのため、污染源の発生位置をパラメーターとした污染 源の人体污染吸入量への寄与を評価する新たな指標を 2 つ提案する。 2.1 CRP1 (Contribution Ratio of Pollution Source 1)

図 1 に示すように、CRP1 $1_{\mathrm{i}}$ はある污染源( $(\mathrm{i})$ 吅室内への污染質発 生量の内、人体が吸入する割合を示す值であり、(1)式で定義される。

$$
\begin{array}{cl}
C R P 1_{i} & =q_{i} / Q_{i} \times 100(\%) \\
q_{i} & : \text { 污染源 }(\mathrm{i}) \text { から発生した污染質の人体吸入量 }(\mathrm{mg} / \mathrm{sec})
\end{array}
$$

$Q_{i} \quad:$ 污染源(i)からの污染質発生量 $(\mathrm{mg} / \mathrm{sec})$

污染源から発生した污染質が人体に吸入されることなく、全て室外 へ排出されると、人体に対する「污染寄与率 CRP1」は $0 \%$ となる。 逆に、それを全て吸入すれば 100\%となる。

\footnotetext{
* (侏)日建設計 工博.

** 東京大学生産技術研究所 教授. 工博

*** 慶應義塾大学理工学部 教授. 工博

**** 東京大学生産技術研究所 産学官連携研究員 - 工博

***** 嶺南大学 専任講師・工博
}

Nikken Sekkei Ltd., Dr. Eng.

Prof., Institute of Industrial Science, University of Tokyo, Ph. D.

Prof., Faculty of Science and Technology, Keio University, Ph. D.

Post Doctor Institute of Industrial Science, University of Tokyo, Dr. Eng.

Lecturer with tenure., Yong-nam University, Dr. Eng. 


\subsection{CRP2 (Contribution Ratio of Pollution Source 2)}

図 1 に示すように、CRP2 2 は人体が吸入する総污染量の内、対象 とする污染源(i)の寄与の割合を示す值であり、(2)式で定義される。
$C R P 2=q_{i} / q_{\text {total }} \times 100(\%)$
$q_{\text {total }}=\sum q_{i}$

$q_{\text {total }}$ :污染源全体からの総污染吸入量 $(\mathrm{mg} / \mathrm{sec})$

\section{3. 静棌室内を対象とした CRP 解析}

人体の污染吸入に関する污染寄与率 CRP は、室形状、換気方式、 室内人体位置、人体姿勢、人体活動（静止もしくは移動）により変 化するものであり、その性状を直ちに包括的に解析することは難し い。ここでは代表性のあると思われる室内形状、換気方式、人体位

置、姿勢などを適切にモデル化し、その概括的性状を検討する。

\section{1 解析対象}

解析対象とする室モデルを図 2 に示す。室内空調方式は、冷たい 新鮮空気を床面近くに低速で供給し、室内熱負荷により加熱された 空気が天井面近くで排出される置換換気方式を採用する注1)。ここで、 人体姿勢による污染寄与率の変化を検討するため、室内の在室人数 を 1 名とし、人体姿勢として、立位（Case1）、臥位（Case2） 注2)の 2 通りに関し検討を行う。立位状態の人体は室中央部に空調吹出口 方向を向いて直立し (図 2(1))、臥位状態の人体は空調吹出気流が呼 吸域に直接及ばないよう、吹出口側に足を向け仰向けに寝ている状 態を想定した（図 2(2)）。

\section{2 解析概要}

解析の概要を表 1 に示す。流れ場解析は標準 $\mathrm{k}-\varepsilon$ モデル（3 次元） による。壁面では風速に対して一般化対数則を適用し文9)、温度場は 人体表面において対流熱伝達量（立位状態：20.0W/ $/ \mathrm{m}^{2}$ 、臥位状態： $\left.30.1 \mathrm{~W} / \mathrm{m}^{2}\right)$ 社3)を与えている。その他の壁面は断熱としている。解析

表 1 解析瀶要

\begin{tabular}{c|c|c}
\hline ケース & Case1 & Case2 \\
\hline 乱流計算モデル & \multicolumn{2}{|c}{ 標準 $\mathrm{k}-\varepsilon$ モデル (三次元) } \\
\hline 差分スキーム & \multicolumn{2}{|c}{ 対流項 : HYBRID } \\
\hline \multirow{3}{*}{ メッシュ分割 } & $\begin{array}{l}\text { BFCを用い、メッシュを分割する。また、Y 方向の空間の } \\
\text { 対称性より半分の領域のみを計算する。 }\end{array}$ \\
\cline { 2 - 3 } & メッシュ数 : 157,841 & メッシュ数 : 142,347 \\
\hline \hline
\end{tabular}

\section{表 2 境界条件}

\begin{tabular}{|c|c|c|}
\hline \multicolumn{2}{|c|}{ 空調の吹出口 } & $\begin{array}{l}\text { 寸法: } 0.27 \mathrm{~m} \text { (休面からの高さ) } \times 0.44 \mathrm{~m} \text { (幅は中心断面に対称) } \\
\text { 速度 : } 0.12 \mathrm{~m} / \mathrm{s} \text { 、風量 : } 0.0143 \mathrm{~m}^{3} / \mathrm{s} \text { 、温度 : } 22^{\circ} \mathrm{C} \\
\text { 風向 : 図 } 2 \text { に参照 } \\
\text { 乱流エネルギ } \text { エ } \mathrm{k}: 2.88 \times 10^{-5} \mathrm{~m}^{2} / \mathrm{s}^{2} \text { 、乱流消散率 } \varepsilon: \\
2.13 \times 10^{-6} \mathrm{~m}^{2} / \mathrm{s}^{3}\end{array}$ \\
\hline \multicolumn{2}{|c|}{ 空調の吸込口 } & $\begin{array}{l}\text { 寸法 : } 0.27 \mathrm{~m} \times 0.44 \mathrm{~m} 、 \text { 速度 : free slip } \\
\text { 温度 : free-slip }\end{array}$ \\
\hline \multicolumn{2}{|c|}{ 壁面 } & 速度 : 一般化対数則、温度 : 一般化対数則、断熱壁 \\
\hline \multirow[t]{2}{*}{ 人 } & 表面 & $\begin{array}{l}\text { 速度 : 一般化対数則 } \\
\text { 温度:表面に } 38.3 \mathrm{~W} \text { の対流熱伝達量を均一に与える(立位状 } \\
\left.\text { 態 : } 20.0 \mathrm{~W} / \mathrm{m}^{2} \text { 、卧位状態 }: 30.1 \mathrm{~W} / \mathrm{m}^{2}\right) \text { 。 }\end{array}$ \\
\hline & 口 & 定常吸気量 : 14.4 㟋/min \\
\hline
\end{tabular}

は複雑人体形状を表現するために BFC（Boundary Fitted Coordinates : 境界適合座標系) を用いて行い、総メッシュを Case1 で 157,841、Case2 で 142,347 とした。

呼吸は非定常現象であるが、口からの呼出空気が、呼吸域に空気 を輸送する室内の大きな流れ構造に与える影響は小さいため注4)、本 解析では定常吸気状態を仮定して計算を行う。吸気量は人体口位置 （開口面積は約 $3.4 \mathrm{~cm}^{2}$ ) で、定常的に 14.4 悦/ $/ \mathrm{min}$ 文 10) 注 5) 吸入する と想定する。これは、室の換気量（855 珖/ $/ \mathrm{min} ）$ の 1.7\%である。

境界条件の詳細を表 2 に示す。室内の定常な流れ場、温度場を初 めに計算し、その流れ場を用いたトレーサーガス拡散解析により CRP1、CRP2の計算を行う。

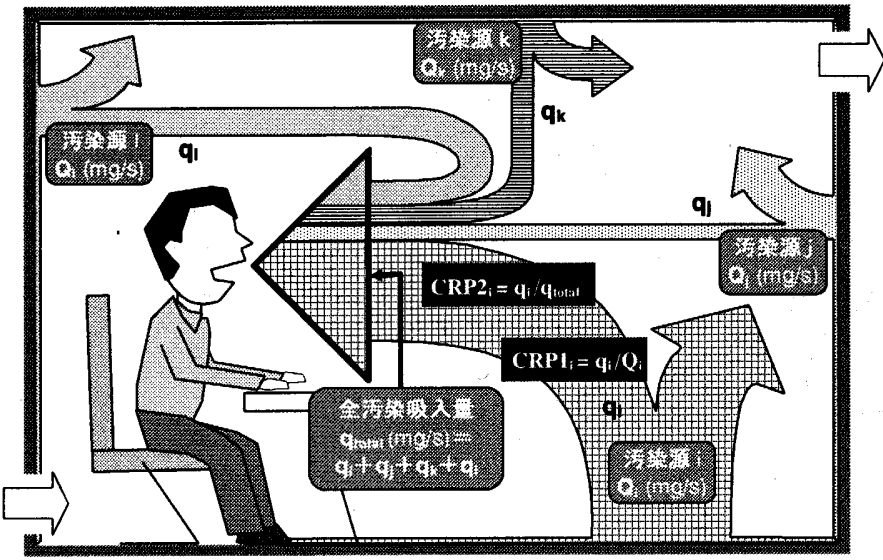

※污染寄与率 CRP2 は、人体の総污染質吸入量の内、各対象発生源の寄与してい る割合を示す值である。

図 1 CRP の掼念図

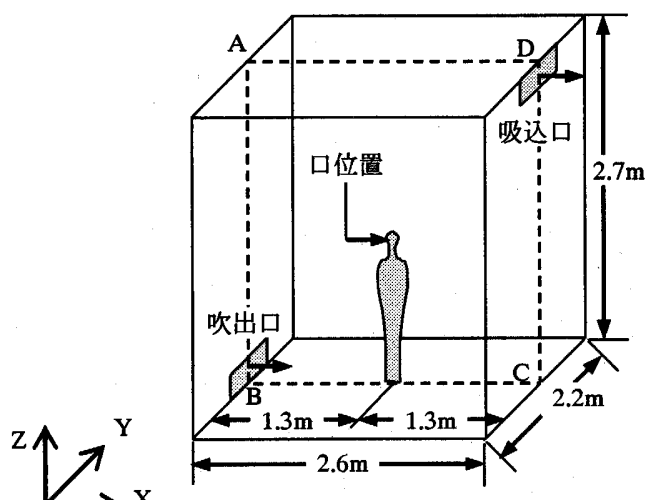

(1) 立位状態 (Case1)

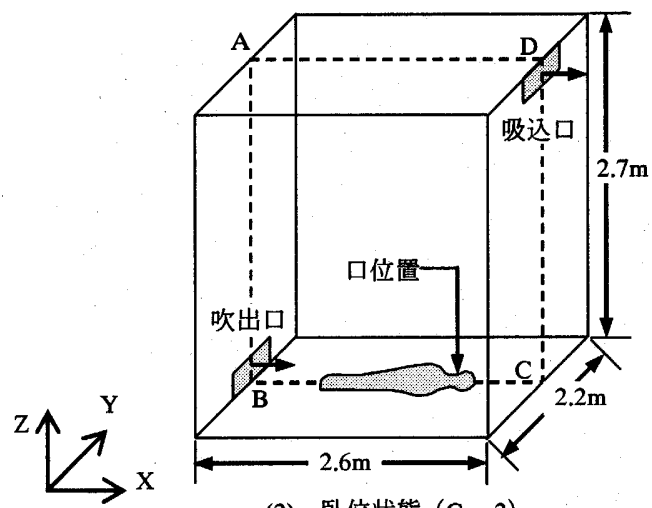

(2) 臥位状態 (Case2)

図 2 解析対象 


\section{3 解析結果}

\subsection{1 温度場（図 3)}

置換換気方式によるピストンフローが室全体に形成され、立位状態 臥位状態の場合において、室内に温度成層が形成されている。発熱 体である人体が床面付近にのみある臥位状態では温度成層が室下部 にのみ形成され、室上部は均質な温度となっている。

\subsection{2 流九場}

(1) 立位状態（図 4(1),(2)）流れ場は室全体としては静穏である。 しかし、人体のまわりにはその生理発熱による上昇流が顕著に生じ ている。人体口位固では定常的な吸気による $0.22 \mathrm{~m} / \mathrm{s}$ 程度の比較的 速い速度が観察される。また、呼吸域には生理発熱による上昇流に より室下部からの空気が流入しており、人体はその上昇空気を吸引 している性状が明瞭に観察される。

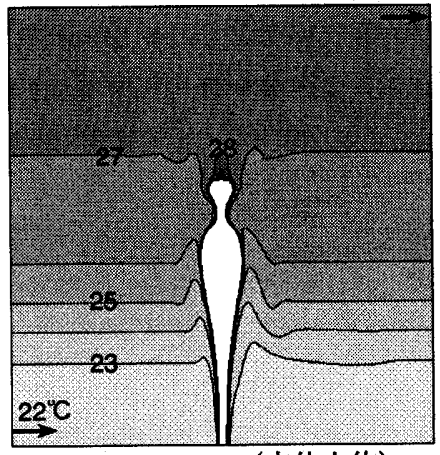

(1) Case 1（立位人体）

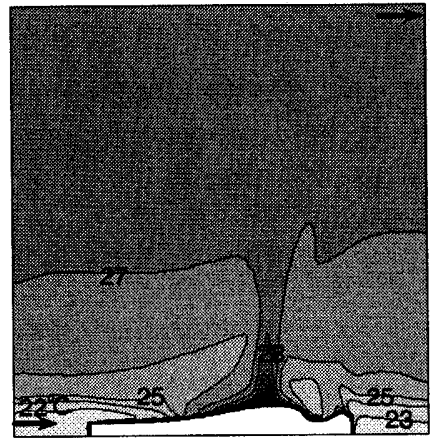

(2) Case 2（臥位人体）
図 3 温度分布 $\left({ }^{\circ} \mathrm{C}\right)$

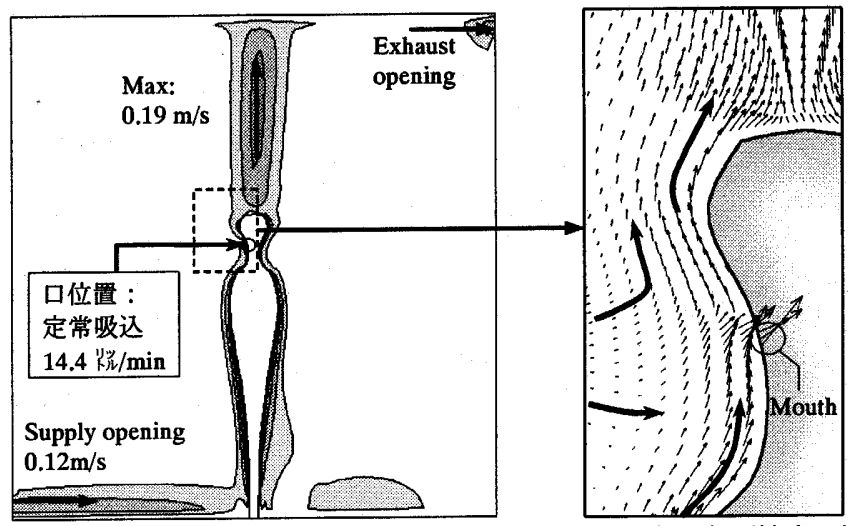

（1） スカラー風速分布 $(\mathrm{m} / \mathrm{s})$

（2）・外風速分布（拡大図）

図 4 Case1 における風速分布（立位人体、ABCD 鈶直断面）

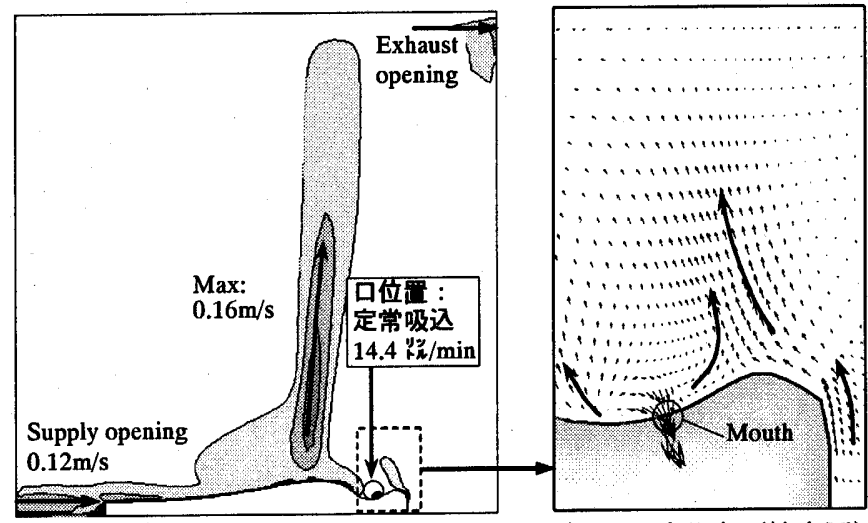

（1） スカラー風速分布 $(\mathrm{m} / \mathrm{s})$

（2）べ外風速分布（拡大図）

図 5 Case2 における風速分布（臥位人体、ABCD 鈶直断面）
（2）臥位状態（図 5(1),(2)） 流机場は立位時と同様に、室全体とし ては静穏であるが、人体近傍では生理発熱による浮力上昇流が人体 に沿いながら人体中心部（胸近傍）に収束し、その上部に上昇流が 生じている。人体中心での上昇流は最大で $0.16 \mathrm{~m} / \mathrm{s}$ 程度となり、立 位時よりやや小さい。呼吸域では、吸気による流れと床面から上昇 してくる流れとが混在し、やや複雑な流れとなっている。

\subsection{3 污染寄与率 CRP1（図 6）}

図 6 に示す床面(F01 06)、壁面(W01～14)、天井面(C01〜06)の小 領域は污染質発生源の位置を示しており、（ ）内の数值が小領域の CRP1 を示している。CRP1 の値は、各污染源表面濃度を 1.0 として、 すなわち発生源強度を同じとして全ての要素に対し個別に拡散解析 注 6)を行った結果である。

(1) 立位状熊（図6(1)）㯰換換気された室内において、CRP1 の值 は室上部と室下部で 2 段階に分かれる。室下部では床面で 2.60 2.81\%、側壁面では $1.66 〜 2.91 \%$ となり比較的均一に分布している。 床面の F05 が污染源である場合の濃度分布を図 7(1)に示す。この場

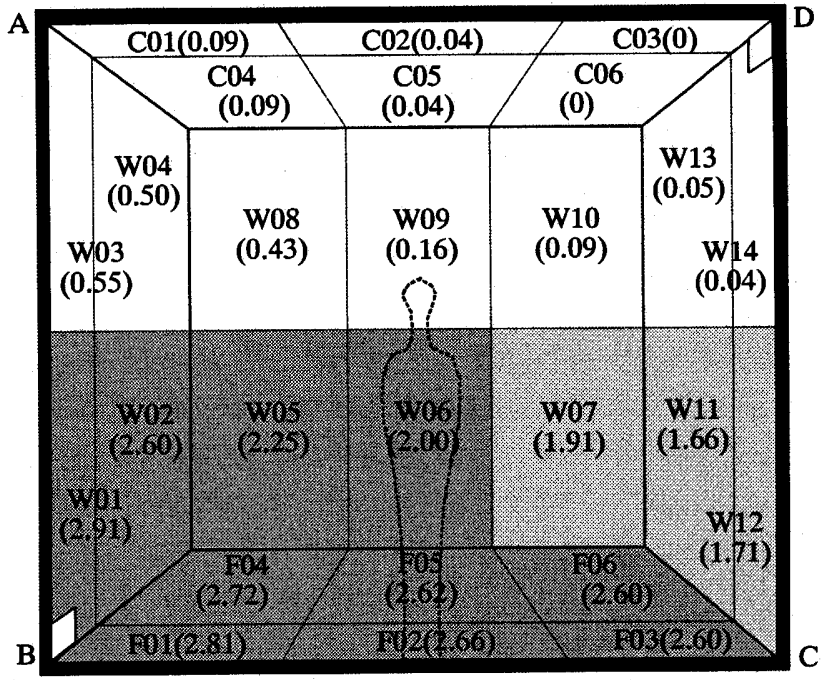

(1) 立位状態（Case1）

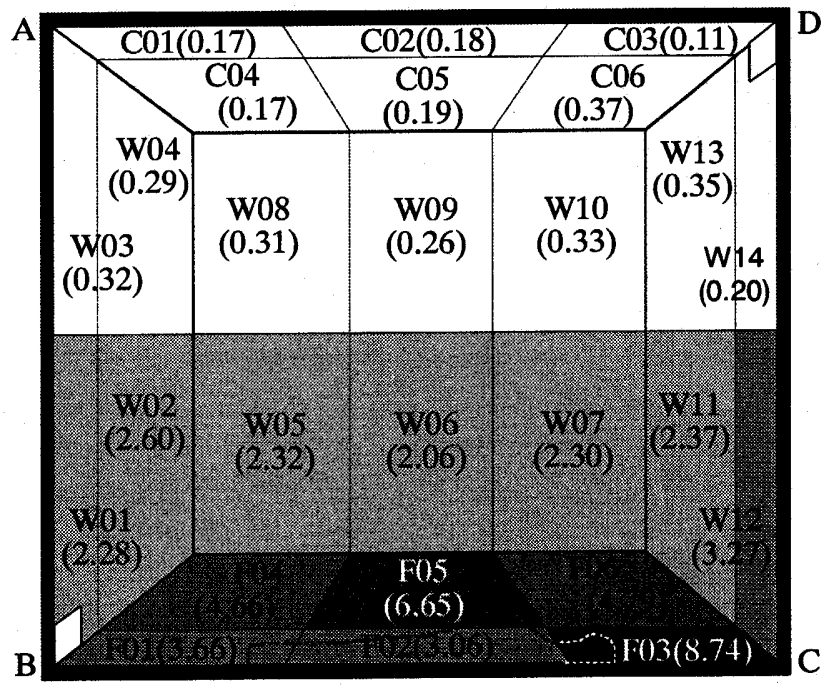

(2) 臥位状態 (Case2)

図 6 各小要素の位置と污染寄与率 CRP1（解析対象の半分を表示） （上段の記号は污染源位置を、下段の括弧内の数値は CRP1 を示す。） 
合、発生した污染質は空調吸込口の反対側になる人体モデル左側(吹 出口側）に滞留するが、人体は空調吹出口からの新鮮空気を効率よ く呼吸域に誘引しているため、CRP1 の值は余り高くならない。同 様の傾向が他の床面から污染質が発生した場合にもいえる。側壁面 (W01〜W14)から污染質が発生した場合、污染質は鉛直方向に成層 化するが、室下部の側壁面から発生した場合（図 7(2)：污染源位置 W12）も、室上部の側壁面から発生した場合（図 7(3)：污染源位置 W10）も、人体は污染源の直接的な影響を強く受けない。また、天 井面から污染質が発生した場合（図 7(4)：污染源位置 C01）は、置 換換気方式の特徴であるピストンフローにより、室上部にのみ滞留 し、室下部の空気とはほとんど混合しないため、CRP1 は 0.1\%以下 となり、人体の呼吸空気質に対する寄与は室内の換気量に対する呼 吸量の割合と比べて非常に低くなる。

（2）臥位状熊（図 6(2)）人体が床面に寝ている場合、立位の場合 と異なり人体の口の位直が床面付近の吸込口側壁面奇りにあるため、 CRP1 の值に分布が生じる。床面の F03 では吹出気流のウェイクに より污染質が人体の頭方向へと流されるため、CRP1 の值は $8.74 \%$ と非常に高い值となる（図 8(1)）。一方、F01，02 では発生した污染 質が人体腰位㯰付近に生じる生理発熱による上昇流と共に室上部へ 速やかに運ばれるため 3 4\%程度の值となっている。また、天井面 での CRP1 は人体が立位状態の場合に比べ総じて高く評価される。 人体の総污染質吸引量は立位状熊の場合に比べて約 1.8 倍である。

\subsection{4 污染奇与專 CRP2（図 9）}

CRP2 は人体が口から吸引する総污染質量の内、ある污染発生源 から発生した污染質がどれくらい寄与しているかを示す指標である。 ここでは直方体の対象室内の(1)床面、(2)吹出口側壁面、(3)吸込口側
壁面、(4)奥側壁面、(5)天井面生 7) をそれぞれ污染源位置と設定し、 各壁面の CRP2 を求める。

(1) 立位状態（図 9(1)）立位の場合、林面(1)の CRP2 は 53\%に達 し、人体が吸引する污染質の半分以上が床面(1)に起因するものであ ることがわかる。すなわち、各壁面から均一に污染質が発生してい ると想定した場合、床面からの污染質発生を 0 に制御できれば、人 体の総污染質吸引量は半分以下になる。また、吹出口位置、吸込口 位置、人体の向きに関わらず、側壁面 (2) (4)) からの寄与は 13〜 17\%で比較的均一になっている。

(2) 臥位状態（図 9(2)）臥位状態の場合、床面(1)の CRP2 は 73\% となり、立位状態の場合よりもさらに高い值となる。側壁面（2) (4)）の CRP2 は立位状態の場合と同様に 7 9\%と比較的均一になる か、、吹出口側壁面(2)の寄与は小さくなる。これは、人体腰付近で発 生する人体周辺の熱上昇流がエアカーテンの役割をし、吹出口側壁 面(2)から発生した污染質を呼吸域に到達する前に、上部へと輸送す る傾向があるためと思われる。天井面(5) CRP2 は 2\%で立位時の場 合と同様に低い值となる。

\section{4. まとめ}

(1)污染源と人体吸気污染の関係を評価する新しい指標として、(1)個 別污染源の人体吸気污染への寄与を評価する污染奇与率 CRP1 と、 (2)個別污染源の人体の総污染質吸入量への寄与を評価する污染 寄与率 CRP2 を提案し、置換換気方式で冷房された室内において、 立位と臥位の人体を対象として解析事例を示した。

(2)立位状態において、CRP1 は室下部で高く、室上部で低い分布と なるが、それぞれで比較的均一に分布する。

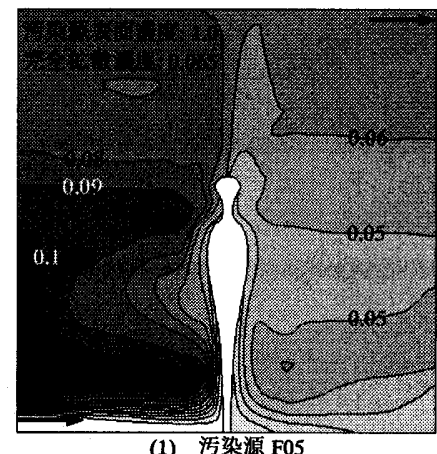

(1) 污染源 F05

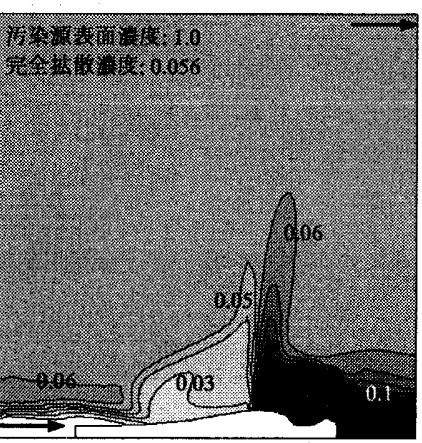

(1) 污染䃥 F05

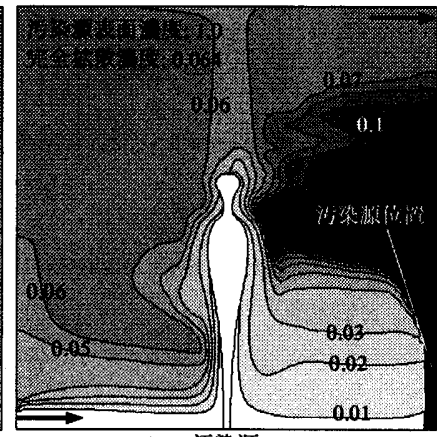

(2) 污染源 W12

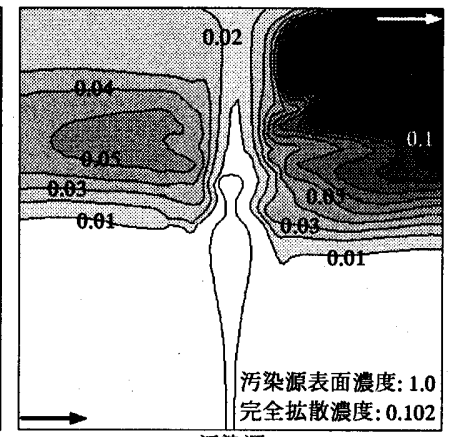

(3) 污染源 W10

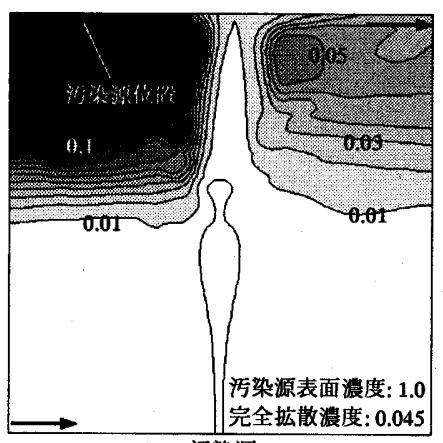

(4) 污染源 $\mathrm{C} 01$

図 7 Case1 における灣度分布（立位状熊、ABCD 鈶直断面）

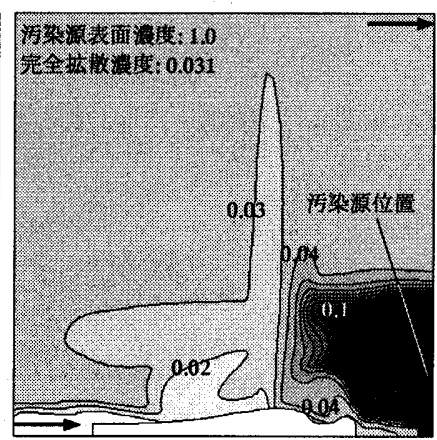

(2) 污染源 W12

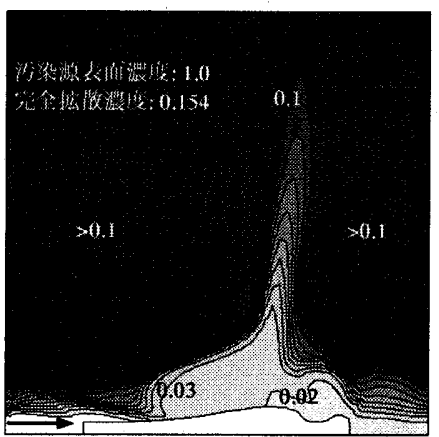

(3) 污染源 W10

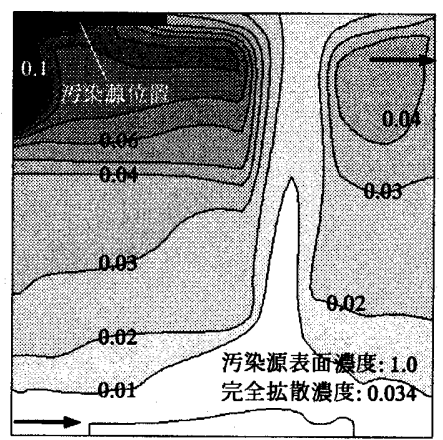

(4) 污染源 $\mathrm{C01}$

図 8 Case2 における灌度分布（臥位状站、ABCD 鉛直断面） 


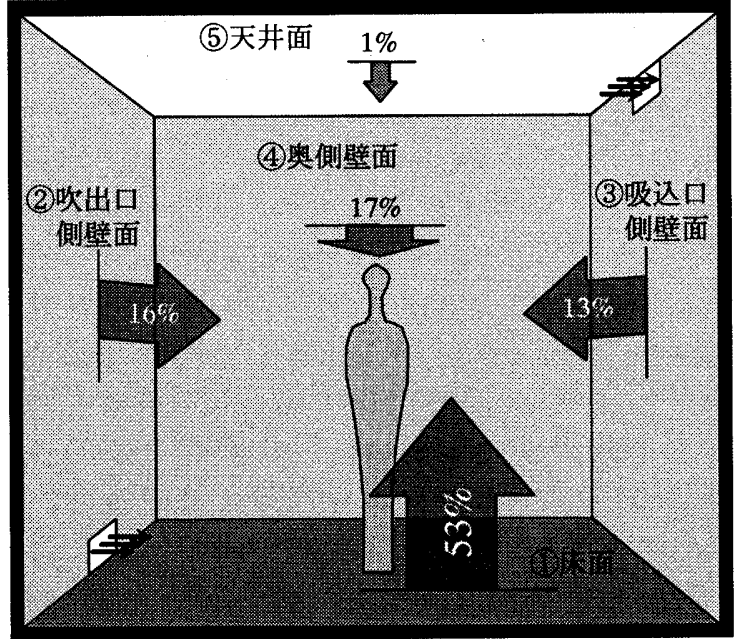

(1) 立位状態 (Case1)

図 9 污染寄与率 CRP2 の分布

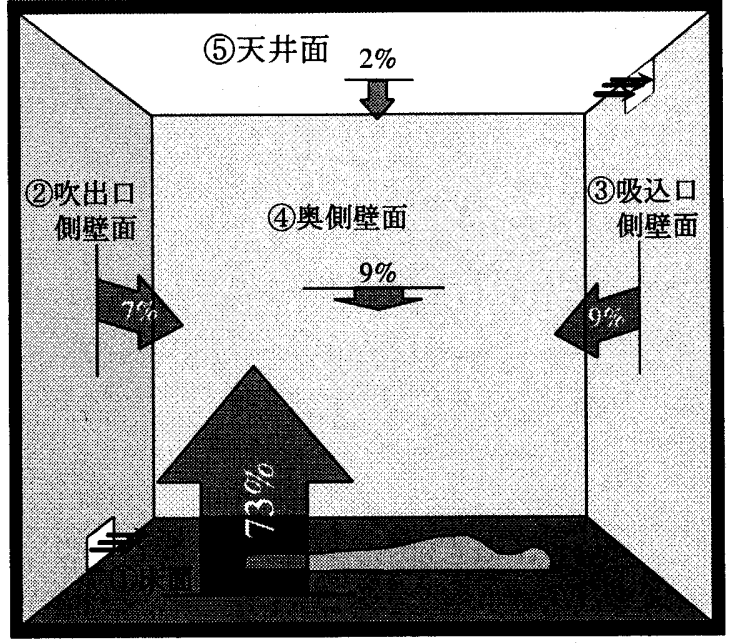

（2）臥位状態（Case2）
(3)臥位状態において、CRP1 は吹出口や吸込口と人体の関係に大き く影響を受けるが、室上部では立位状態の場合と同様に非常に低 い値となる。

(4)立位状態、臥位状態において、CRP2 は床面で圧倒的に高い值を 示し、置換換気された室内では床面の清浄化対策が人体呼吸空気 污染を防ぐことが示唆された。

注 1）解析対象室内で想定している置換換気方式は、住宅の居室等 における、内外温度差が大きく換気回数が小さい煙突効果に よる換気と類似したものである。

注 2 ）臥位状態の人体形状は、立位状態の人体形状を基本的に踏襲 しているが、床面に接する部分は平面となっている。但し、 体積を立位状態のそれと等しくするために多少のモデル化を 施している。

注 3）人体代謝量は人体の活動状況によって異なるが、ここでは比 較のため立位状態と臥位状態で発生熱量、すなわち対流熱伝 達量を等しくしている。また、臥位状態の人体においては、 室内空気に接する体表面積が小さいため、総発熱量（33.8W） が立位時の人体と等しくなるように対流熱伝達率を割り増し している。

注 4) 本解析では呼吸現象を定常吸気と仮定して解析を行う。これ に関しては、PIV 風速計を用いた呼吸するサーマルマネキン 呼吸域の風速測定、及び呼吸域の非定常解析により、人体呼 吸域の流れ構造が呼吸の非定常性の影響を大きく受けないこ とを確認した文11)。

注 5) 呼吸量は酸素消費量（活動量）から求まるが、ここでは比較 のため立位状態と臥位状態で同量を仮定している。また、今 回の呼吸量は $6.0 \mathrm{k} / \mathrm{m} / \mathrm{min}$ (呼吸回数は 10 回 $/ \mathrm{min}$ 。すなわち 0.6 恍/回）の呼吸現象の吸気部分が均一に定常的に続くと想定し ている文11。

注 6) 濃度計算はガス状污染質を想定し、シュミット数を 1 とした CFD の Passive Scalar 解析法により行っている。

注 7) 各微小面要素の面積比は最大で(床面) : (奥側壁面) $=1: 1.2$ 程 度である。

\section{参考文献}

1) Wadden RA, Scheff PA. : Indoor Air Pollution. New York: Wiley-Interscience, 1983

2) Editorials. Sick Building Syndrome, the Lancet 1991, 338:1493-4

3) M. Sandberg : Ventilation effectiveness and purging flow rate - A review. International Symposium on Room Air Convection and Ventilation Effectiveness, University of Tokyo, ISRACVE ASHRAE, pp17, 1992.7

4) S. Kato, S. Murakam, and J, Zeng. : Numerical Analysis of Contaminant Distribution around a Human Body, Roomvent'96, Vol.2, pp.129-136, 1996.7

5) T. Hayashi, Y. Ishizu, S. Kato, and S. Murakami : CFD Analysis on Characteristics of Contaminated Indoor Air Ventilation and its Application in the Evaluation of the Effects of Contaminant Inhalation by a Human Occupant, Building and Environment, 37, pp.219-230, 2002

6) SW. Zhu, S. Kato, S. Murakami, and Y. Hayashi : Study on Inhalation Region by Means of CFD Analysis and Experiment, Building and Environment, 40, 2005

7) M.G. Apte., and J.M. Daiscy : VOCs and "Sick Building Syndrome": Application of a New Statistical Approach for SBS Research to U.S. EPA Base Study Data., Indoor Air' 99, 1, 117-122, 1999.8

8) 加藤、曾、村上 : 数値サーマルマネキンに関する研究（その 2) 静榣環境下における立位人体周囲の污染質濃度分布に関する CFD 解析、日本建築学会計画系論文集、No.509、pp.21-26, 1998

9) B.E. Launder, and D.B. Spalding : The Numerical Computation of Turbulent Flows, Computer Methods in Applied Mechanics and Engineering, 3, pp.269-289, 1974

10) 温熱生理学、中山昭雄編、理工学社、1981

11) 朱、林、加藤、村上 : 可視化実験と数値解析による静稳室内の 人体呼吸域流れ性状の検討、日本建築学会環境系論文集、No.583, pp.37-52, 2004,9 